\title{
Germination of sh2 Sweet Corn following Seed Disinfestation, Solid-matrix Priming, and Microbial Seed Treatment
}

\author{
T.K. Hartz and J. Caprile ${ }^{1}$ \\ Department of Vegetable Crops, University of California, Davis, CA 95616
}

Additional index words. Zea mays, biological control, stand establishment

\begin{abstract}
Sweet corn (Zea mays L.) cultivars carrying the sh2 mutation show poor seed vigor under stressful field conditions, requiring higher seeding rates to ensure stand establishment. The effects of sodium hypochlorite seed disinfestation, solid matrix priming (SMP), and seed-coating with Gliocladium virens Miller, Giddens \& Foster to enhance emergence of $s h 2$ sweet corn in controlled-environment cold stress tests and field trials were investigated. In combination with a chemical fungicide seed treatment (captan, thiram, imazalil, and metalaxyl), SMP significantly improved the percentage and rate of seedling emergence of 'Excel' and 'Supersweet Jubilee' in a cold stress test (in soil for 7 days at $10 \mathrm{C}$, then $15 \mathrm{C}$ until emergence) but was inconsistent under field conditions, improving emergence in only one of four field trials. Sodium hypochlorite disinfestation was ineffective. Compared to a film-coated control, coating seeds with $G$. virens strain G-6 was highly effective in increasing emergence in two of three cultivars tested in cold stress tests in two soils, while strain G-4 was generally ineffective. In field trials, G-6 treatment significantly increased emergence over that of nontreated seed but was inferior to conventional fungicide treatment and conferred no additional benefit in combination with fungicide treatment. Overall, no seed treatment evaluated was an economically viable alternative for or supplement to chemical fungicide treatment. Chemical names used: cis$\mathrm{N}$-trichloromethylthio-4-cyclohexene-1,2-dicarboximide (captan); tetramethyl-thiuram disulfide (thiram); 1-[2-(2,4-dichlorophenyl)-2-(2-propenyloxy)ethyl]-1H-imidazole (imazalil); $N$-(2,6-dimethylphenyl)- $N$-(methoxyacetyl)-alanine methyl ester (metalaxyl).
\end{abstract}

Supersweet sweet corn cultivars (those carrying the $s h 2$ mutation) now dominate the fresh-market sweet corn industry in the United States due to extended shelf life and excellent eating quality. However, seedling emergence and vigor are negatively affected by the mutant sh2 gene (Cantliffe et al., 1975). Stand establishment is problematic when soil conditions, particularly temperature, are suboptimal. Poor seedling vigor of $s h 2$ cultivars has been attributed to several factors. The small endosperm has minimal nutrient reserves ( $\mathrm{He}$ and Burris, 1992; Wann, 1980). Rate of imbibition and electrolyte leakage are high, which may enhance susceptibility to preemergence damping-off (Parera and Cantliffe, 1991). Seed lots are frequently infected with Fusarium moniliforme J. Sheld. and Penicillium oxalicum Currie \& Thom (Mohan and Wilson, 1990). Also, cracks in the pericarp of sh2 kernels allow pathogen entry into the endosperm and embryo (Styer and Cantliffe, 1983).

Chemical, physiological, and microbial seed treatments to improve $s h 2$ seedling emergence have been investigated extensively. Fungicide seed treatments significantly improved

Received for publication 29 Mar. 1995. Accepted for publication $16 \mathrm{Aug}$. 1995. The cost of publishing this paper was defrayed in part by the payment of page charges. Under postal regulations, this paper therefore must be hereby marked advertisement solely to indicate this fact.

${ }^{1}$ Current address: Univ. of California Cooperative Extension, Contra Costa County. sweet corn seedling emergence (Callan et al., 1991; Parera and Cantliffe, 1990, 1994); seed treatments with a combination of broadspectrum fungicides are used commercially. Parera and Cantliffe (1991) reported that sodium hypochlorite was an effective seed disinfestant. Presowing hydration (Bennett and Waters, 1987; Gerber and Caplan, 1989), osmopriming (Murray, 1990), and solidmatrix priming (SMP) (Harman and Taylor, 1989; Parera and Cantliffe, 1990, 1994) have improved $s h 2$ germination. Callan et al. (1990, 1991) reported that applying Pseudomonas fluorescens Migula, alone or in combination with seed priming, reduced seedling loss to Pythium ultimum Trow and increased field establishment of $s h 2$ corn. Harman and Taylor (1989) showed similar results using Trichoderma harzianum Rifai.

The success of biological and physiological seed treatments in improving seedling emergence has been highly variable. We conducted this study to determine the effects of SMP, sodium hypochlorite, and application of microbial protectants on $s h 2$ corn seedling emergence under field conditions representative of the central California sweet-corn industry. These techniques were chosen for evaluation because they showed the greatest potential for commercialization.

\section{Materials and Methods}

Experiments were performed at the Univ. of California-Davis (UCD) and in commer- cial sweet-corn fields near Brentwood, Calif., during 1992 and 1993. Commercial seed lots of 'Excel', 'Supersweet Jubilee' (both years), and 'How Sweet It Is' (HSII) (1993 only) were used.

Seed disinfestation. Seeds were soaked for $15 \mathrm{~min}$ in $0.05 \%$ a.i. solution of sodium hypochlorite $(\mathrm{NaOCl})$ at $22 \pm 2 \mathrm{C}$, then triplerinsed with tap water (Parera and Cantliffe, 1991), and air-dried for at least 2 days before planting.

$S M P$. Seed, finely ground Leonardite shale (Agro-Lig, American Colloid Co., Arlington Heights, Ill.), and distilled water with $0.1 \%$ Tween 80 were thoroughly blended (Taylor et $\mathrm{al}, 1988)$ at a 1.0:1.5:0.85 (w/w/v) ratio and were incubated for $48 \mathrm{~h}$ at $20 \pm 1 \mathrm{C}$. After treatment, the seed was screened to remove most of the shale particles and air-dried at 22 $\pm 2 \mathrm{C}$ for at least 2 days before sowing. Where combinations of $\mathrm{NaOCl}$ disinfestation and SMP were used, $\mathrm{NaOCl}$ treatment preceded SMP.

A preliminary test in field soil showed poor emergence by SMP- and/or NaOCl-treated seed in the absence of fungicide protection; all $\mathrm{SMP}$ and $\mathrm{NaOCl}$ treatments described in this study were in conjunction with the industry standard combination fungicide treatment (captan, thiram, imazalil, and metalaxyl at 1.25, $1.25,0.9$, and $0.5 \mathrm{~g}$ a.i./kg seed).

Biological treatment. Conidia of strains G-4 and G-6 of Gliocladium virens on granulated moist millet seed were obtained from $\mathrm{C}$. Howell, Texas A\&M Univ., College Station. These organisms have shown promise as biological seed treatments (Howell, 1991; Howell et al., 1993). Seeds were coated with an aqueous solution of film-forming polymer (Opadry AG Blue, Colorcon, West Point, Pa.) into which the Gliocladium inoculum was mixed. Seed then were forced-air-dried at $25 \mathrm{C}$ in a rotating drum. The dried coating comprised $\approx 2 \%$ of seed weight. The amount of each Gliocladium strain added to the coating material was controlled to deliver $\approx 30,000$ colonyforming units per coated seed.

Controlled-environment stress tests. SMP and $\mathrm{NaOCl}$ treatments were evaluated in Feb. 1992 by planting into moist field soil in plastic boxes; the soil (Yolo clay loam), collected from a fallow field at UCD in which corn had been grown the previous summer, was prechilled to 10C. After planting, the boxes were kept at 10C for 7 days and then transferred to $15 \mathrm{C}$. Germination counts were taken

Table 1. Effect of sodium hypochlorite $(\mathrm{NaOCl})$ and solid-matrix priming (SMP) on seedling emergence of $\operatorname{sh} 2$ corn in a 1992 controlledenvironment stress test.

\begin{tabular}{|c|c|c|c|}
\hline \multirow[b]{3}{*}{ Treatment } & \multirow{2}{*}{\multicolumn{2}{|c|}{$\frac{\text { Emergence }(\%)}{\text { Cultivar }}$}} & \multirow[b]{3}{*}{$\mathrm{T}_{50}^{\mathrm{y}}$} \\
\hline & & & \\
\hline & Excel & Jubilee & \\
\hline Funcicide (F) & $68 b^{x}$ & $74 \mathrm{~b}$ & $14.9 \mathrm{~b}$ \\
\hline $\mathrm{F}+\mathrm{NaOCl}$ & $73 \mathrm{ab}$ & $73 \mathrm{~b}$ & $15.2 \mathrm{~b}$ \\
\hline $\mathrm{F}+\mathrm{SMP}$ & $83 \mathrm{a}$ & $90 \mathrm{a}$ & $13.5 \mathrm{a}$ \\
\hline $\mathrm{F}+\mathrm{NaOCl}+\mathrm{SMP}$ & $81 \mathrm{a}$ & $89 \mathrm{a}$ & $13.5 \mathrm{a}$ \\
\hline
\end{tabular}


daily for 14 days at $15 \mathrm{C}$. Gliocladium treatments were similarly evaluated in Apr. 1993 using soil from two UCD fields in which stand establishment tests were being conducted concurrently.

Field trials. Four field trials evaluating SMP and $\mathrm{NaOCl}$ were conducted in 1992 and 1993, two at UCD and two in commercial sweet-corn fields near Brentwood, Calif. Planting dates were 3 and 15 Mar. (Brentwood) and 31 and 22 Mar. (UCD) in 1992 and 1993, respectively. March is the beginning of the traditional planting season for $s h 2$ cultivars in central California. Replicates of 100 seeds were planted in a clay loam (Brentwood) or a sandy loam (UCD) soil in a randomized complete-block design, with four (Brentwood) or five (UCD) replications per treatment/cultivar. Sprinkler irrigation was applied at UCD; no irrigation was used in Brentwood.

Two trials for evaluating $G$. virens treatments were conducted at UCD in 1993. Replicates of 100 seeds were planted into a clay loam (soil 1; 2 Apr.) and a sandy loam (soil 2; 12 Apr.). Sprinkler irrigation was applied in both trials. The design was a randomized complete block with five replications per treatment/cultivar. Stand counts were taken at 2- to 4-day intervals until emergence was complete. All statistical analyses of emergence data were conducted following arcsinetransformation. Emergence rate was determined by the time required for $50 \%\left(\mathrm{~T}_{50}\right)$ of the seedlings to emerge (Alvarado et al., 1987).

\section{Results and Discussion}

The controlled-environment stress test showed that SMP, with or without $\mathrm{NaOCl}$, improved the percentage and rate of seedling emergence compared to the fungicide-only control (Table 1). The $\mathrm{NaOCl}$ treatment did not improve emergence over fungicide alone.

In 1992 field trials, SMP treatment improved emergence in both cultivars tested in the Brentwood trial but was ineffective at UCD (Table 2). $\mathrm{NaOCl}$ alone was effective only on 'Excel' at Brentwood, while $\mathrm{NaOCl}$ disinfestation before SMP gave no benefit beyond that shown by SMP alone. Percent emergence in both field trials was substantially lower than in the stress test, despite a less severe temperature regime. Only small differences were measured in $\mathrm{T}_{50}$ due to treatment. In 1993 field trials, emergence from seed without fungicide was lower than for all other treatments (Table 2). SMP improved emergence of 'Supersweet Jubilee' compared to the fungicide control in Brentwood but had no effect at UCD. At either site, $\mathrm{NaOCl}$ was ineffective.

Gliocladium strain G-6, applied in a film coating (FC), significantly improved emergence compared to the film-coated control in two of three cultivars tested in both soils in the stress tests (Table 3). G-4 did not improve emergence over film-coating alone. All samples treated with fungicides had high emergence and neither G-6 nor G-4 improved emergence further. In field trials, both strains were inferior to the fungicide combination in in- creasing emergence (Table 4). The film coating had a marginal effect on emergence, significantly decreasing the stand of HSII only in sandy loam. Neither strain improved emergence of fungicide-treated seed.

Parera and Cantliffe $(1990,1994)$ reported that the SMP and $\mathrm{NaOCl}$ combination was a viable alternative to fungicide treatment for enhancing sh2 sweet-corn germination. Our preliminary results of the cold stress test suggest that SMP $+\mathrm{NaOCl}$ is not a useful treatment without the addition of fungicides. This discrepancy could relate to the difference in SMP media and technique or to the more

Table 2. Effect of sodium hypochlorite $(\mathrm{NaOCl})$ and solid matrix priming (SMP) on seedling emergence of $s h 2$ corn in field trials.

\begin{tabular}{|c|c|c|c|c|c|c|c|c|}
\hline \multirow[b]{5}{*}{ Treatment } & \multicolumn{6}{|c|}{ Emergence (\%) } & \\
\hline & \multicolumn{6}{|c|}{ Location } & & \\
\hline & \multirow{2}{*}{\multicolumn{3}{|c|}{$\begin{array}{c}\text { Brentwood, Calif. } \\
\text { Cultivar }\end{array}$}} & \multirow{2}{*}{\multicolumn{3}{|c|}{$\begin{array}{l}\text { UCD }^{z} \\
\text { Cultivar }\end{array}$}} & \multirow{2}{*}{\multicolumn{2}{|c|}{$\frac{\mathrm{T}_{50}{ }^{\mathrm{y}}}{\text { Location }}$}} \\
\hline & & & & & & & & \\
\hline & Excel & $\mathrm{HSII}^{\mathrm{x}}$ & Jubilee & Excel & HSII $^{\mathrm{x}}$ & $\overline{\text { Jubilee }}$ & Brentwood & $\overline{\mathrm{UCD}}$ \\
\hline \multicolumn{9}{|l|}{1992} \\
\hline Fungicide $(\mathrm{F})$ & $15 \mathrm{c}^{\mathrm{w}}$ & & $28 \mathrm{~b}$ & $33 \mathrm{a}$ & & $43 \mathrm{a}$ & $17.9 \mathrm{~b}$ & $11.1 \mathrm{ab}$ \\
\hline $\mathrm{F}+\mathrm{NaOCl}$ & $32 \mathrm{~b}$ & & $32 \mathrm{~b}$ & $32 \mathrm{a}$ & & $38 \mathrm{a}$ & $17.5 \mathrm{~b}$ & $11.4 \mathrm{~b}$ \\
\hline $\mathrm{F}+\mathrm{SMP}$ & $55 \mathrm{a}$ & & $43 \mathrm{a}$ & $43 \mathrm{a}$ & & $35 \mathrm{a}$ & $16.9 \mathrm{a}$ & $10.8 \mathrm{a}$ \\
\hline $\mathrm{F}+\mathrm{NaOCl}+\mathrm{SMP}$ & $43 \mathrm{a}$ & & $43 \mathrm{a}$ & $37 \mathrm{a}$ & & $39 \mathrm{a}$ & $16.9 \mathrm{a}$ & $11.1 \mathrm{ab}$ \\
\hline \multicolumn{9}{|l|}{1993} \\
\hline Nontreated & $16 \mathrm{c}$ & $5 \mathrm{~b}$ & $10 \mathrm{~d}$ & $21 \mathrm{~b}$ & $8 \mathrm{~b}$ & $16 \mathrm{~b}$ & $12.8 \mathrm{c}$ & $14.1 \mathrm{~b}$ \\
\hline $\mathrm{F}$ & $32 \mathrm{ab}$ & $25 \mathrm{a}$ & $29 \mathrm{bc}$ & $35 \mathrm{a}$ & $28 \mathrm{a}$ & $38 \mathrm{a}$ & $12.8 \mathrm{c}$ & $13.7 \mathrm{~b}$ \\
\hline $\mathrm{F}+\mathrm{NaOCl}$ & $30 \mathrm{~b}$ & $28 \mathrm{a}$ & $25 \mathrm{c}$ & $37 \mathrm{a}$ & $25 \mathrm{a}$ & $38 \mathrm{a}$ & $12.3 \mathrm{~b}$ & $13.8 \mathrm{a}$ \\
\hline $\mathrm{F}+\mathrm{SMP}$ & $32 \mathrm{ab}$ & $28 \mathrm{a}$ & $38 \mathrm{a}$ & $33 \mathrm{a}$ & $26 \mathrm{a}$ & $37 \mathrm{a}$ & $12.2 \mathrm{~b}$ & $12.9 \mathrm{a}$ \\
\hline $\mathrm{F}+\mathrm{NaOCl}+\mathrm{SMP}$ & $37 \mathrm{a}$ & $30 \mathrm{a}$ & $34 \mathrm{ab}$ & $32 \mathrm{a}$ & $30 \mathrm{a}$ & $40 \mathrm{a}$ & $11.8 \mathrm{a}$ & $12.3 \mathrm{a}$ \\
\hline
\end{tabular}

${ }^{2} \mathrm{UCD}=$ Univ. of California-Davis.

${ }^{y}$ Mean days to emergence, across cultivars.

${ }^{x} \mathrm{HSII}=$ 'How Sweet It Is'.

wMean separation within columns and years by Duncan's multiple range test at $P \leq 0.05$.

Table 3. Effect of coating seeds with Gliocladium virens strains G-4 and G-6 on seedling emergence of sh2 corn in a 1992 controlled-environment stress test. ${ }^{\mathrm{Z}}$

\begin{tabular}{|c|c|c|c|c|c|c|}
\hline \multirow[b]{5}{*}{ Treatment } & \multicolumn{6}{|c|}{ Emergence $(\%)$} \\
\hline & \multicolumn{6}{|c|}{ Soil type } \\
\hline & \multicolumn{3}{|c|}{ Clay loam } & \multicolumn{3}{|c|}{ Sandy loam } \\
\hline & \multicolumn{3}{|c|}{ Cultivar } & \multicolumn{3}{|c|}{ Cultivar } \\
\hline & Excel & HSII $^{y}$ & Jubilee & Excel & HSII $^{y}$ & Jubilee \\
\hline Nontreated & $33 c^{x}$ & $11 \mathrm{c}$ & $23 \mathrm{~b}$ & $48 \mathrm{~d}$ & $11 \mathrm{c}$ & $13 \mathrm{c}$ \\
\hline Fungicide (F) & $79 a$ & $88 \mathrm{a}$ & $93 \mathrm{a}$ & $86 \mathrm{a}$ & $88 \mathrm{a}$ & $88 \mathrm{a}$ \\
\hline Film-coated (FC) & $55 \mathrm{bc}$ & $13 \mathrm{c}$ & $18 \mathrm{~b}$ & $50 \mathrm{~cd}$ & $10 \mathrm{c}$ & $21 \mathrm{bc}$ \\
\hline $\mathrm{G}-4+\mathrm{FC}$ & $31 \mathrm{c}$ & $14 \mathrm{c}$ & $28 \mathrm{~b}$ & $65 \mathrm{~b}$ & $10 \mathrm{c}$ & $31 \mathrm{~b}$ \\
\hline $\mathrm{G}-4+\mathrm{FC}+\mathrm{F}$ & $89 a$ & $78 \mathrm{ab}$ & $85 \mathrm{a}$ & & & \\
\hline $\mathrm{G}-6+\mathrm{FC}$ & $76 \mathrm{ab}$ & $65 \mathrm{~b}$ & $85 \mathrm{a}$ & $63 \mathrm{bc}$ & $75 \mathrm{~b}$ & $90 \mathrm{a}$ \\
\hline $\mathrm{G}-6+\mathrm{FC}+\mathrm{F}$ & $85 \mathrm{a}$ & $81 \mathrm{a}$ & $85 \mathrm{a}$ & & & \\
\hline
\end{tabular}

${ }^{2}$ Seven days at $10 \mathrm{C}$, then 14 days at $15 \mathrm{C}$.

'HSII = 'How Sweet It Is'.

${ }^{x}$ Mean separation within columns by Duncan's multiple range test at $P \leq 0.05$.

Table 4. Effect of coating seeds with Gliocladium virens on seedling emergence of $\operatorname{sh} 2$ corn in 1992 field trials.

\begin{tabular}{|c|c|c|c|c|}
\hline \multirow[b]{4}{*}{ Treatment } & \multicolumn{4}{|c|}{ Emergence (\%) } \\
\hline & \multicolumn{2}{|c|}{ Clay loam } & \multicolumn{2}{|c|}{ Sandy loam } \\
\hline & \multicolumn{2}{|c|}{ Cultivars } & \multicolumn{2}{|c|}{ Cultivars } \\
\hline & Excel & $\overline{\text { HSII }^{2}}$ & Excel & $\mathrm{HSII}^{\mathrm{z}}$ \\
\hline Nontreated & $31 \mathrm{c}^{\mathrm{y}}$ & $18 \mathrm{c}$ & $26 \mathrm{de}$ & $9 \mathrm{c}$ \\
\hline Fungicide (F) & $49 \mathrm{a}$ & $44 \mathrm{a}$ & $42 \mathrm{ab}$ & $37 \mathrm{a}$ \\
\hline Film-coated (FC) & $32 \mathrm{bc}$ & $13 \mathrm{c}$ & $28 \mathrm{~cd}$ & $4 d$ \\
\hline $\mathrm{G}-4+\mathrm{FC}$ & $33 \mathrm{bc}$ & $18 \mathrm{c}$ & $21 \mathrm{e}$ & $8 \mathrm{c}$ \\
\hline $\mathrm{G}-4+\mathrm{FC}+\mathrm{F}$ & $51 \mathrm{a}$ & $41 \mathrm{a}$ & $40 \mathrm{ab}$ & $36 a$ \\
\hline $\mathrm{G}-6+\mathrm{FC}$ & $36 \mathrm{~b}$ & $29 \mathrm{~b}$ & $33 \mathrm{bc}$ & $19 \mathrm{~b}$ \\
\hline $\mathrm{G}-6+\mathrm{FC}+\mathrm{F}$ & $49 \mathrm{a}$ & $41 \mathrm{a}$ & $44 \mathrm{a}$ & $34 \mathrm{a}$ \\
\hline
\end{tabular}

${ }^{2} \mathrm{HSII}=$ 'How Sweet It Is'.

${ }^{y}$ Mean separation within columns by Duncan's multiple range test at $P \leq 0.05$. 
slowest emergence rate. These results agree with those of Parera and Cantliffe (1994) who found SMP ineffective in improving field performance of fungicide-treated $s h 2$ seed. Where SMP did improve emergence in our study, it may have been related to the increased speed of emergence of SMP-treated seed, which limited time of exposure to soil or seedcoat pathogens. Enhanced speed of germination with SMP or other priming techniques has been consistently reported. The bulky nature of and high seeding rate typical for sweet corn would make SMP an expensive treatment in relation to seed cost. Given the inconsistent field performance, SMP does not appear to be a commercially viable treatment as long as chemical fungicides remain available.

The $\mathrm{NaOCl}$ treatment generally was ineffective in improving seedling emergence. The $\mathrm{NaOCl}$ treatment we used had significantly reduced fungal pathogen infection of $s h 2$ seedcoats (Parera and Cantliffe, 1991). The lack of effectiveness of $\mathrm{NaOCl}$ suggested that seedcoat infection was not a significant factor in limiting emergence in our study. Other investigators (Headrick and Pataky, 1989; Schoen and Kulik, 1977) reported that $F$. moniliforme, the most common pathogen infesting $s h 2$ corn seedcoats, was a minor factor in stand establishment.

Gliocladium virens strain G-6 generally provided some seedling protection in laboratory stress tests and field trials, while G-4 was generally ineffective. Both strains are effective biocontrol agents but with different mechanisms of action (Howell, 1991; Howell et al., 1993). G-4 produced the antibiotic gliovirin and was effective in suppressing $P$. ultimum, while G-6 produced gliotoxin and suppressed Rhizoctonia solani Kuehn. While G-6-treated seed performed at or near the level of fungicide-treated seed in the laboratory trials, it was relatively less effective in the field trials. Howell (1991) reported synergism between $G$. virens and metalaxyl treatment. We did not find synergism, undoubtedly due to the broadspectrum action of the fungicide combination used.

Other investigators reported significant improvement of sh 2 corn stand establishment with biological seed treatments. Harman and Taylor (1989) found T. harzianum suppressed P. ultimum-induced damping-off. Callan et al.
(1990, 1991) showed similar activity with $P$. fluorescens. The weakness in biological seed treatment has been that no agent has been identified that has activity against the range of soil pathogens commonly encountered. Conceptually, a combination of organisms may provide the broad-spectrum suppression of damping-off organisms provided by the fungicide combination treatment, but this suppression has not been demonstrated under representative field conditions.

In field trials, seedling emergence was consistently lower than that achieved in the laboratory cold stress tests, even though field temperature regime was less extreme than the laboratory test. Factors other than temperature and soil pathogen population, notably soil crusting, aeration, and moisture content, appear to play an important role in limiting sh2 corn stand establishment. Presowing seed treatments are unlikely to consistently reduce the effects of these factors.

SMP and $\mathrm{NaOCl}$ were not consistently effective in improving sh 2 corn seedling emergence, either alone or in combination with a combination fungicide treatment. Gliocladium virens strain G-6 showed promise as a biological seed treatment but was less effective than the chemical fungicide combination under field conditions.

\section{Literature Cited}

Alvarado, A.D., K.J. Bradford, and J.D. Hewitt. 1987. Osmotic priming of tomato seed: Effects on germination, field emergence, seedling growth and fruit yield. J. Amer. Soc. Hort. Sci. 112:427-432.

Bennett, M.A. and L. Waters. 1987. Germination and emergence of high sugar sweet corn is improved by presowing hydration of seed. HortScience 22:236-238.

Callan, N.W., D.E. Mathre, and J.B. Miller. 1990. Biopriming seed treatment for biological control of Pythium ultimum preemergence damping-off in sh2 sweet corn. Plant Dis. 74:368372.

Callan, N.W., D.E. Mathre, and J.B. Miller. 1991. Field performance of sweet corn seed bioprimed and coated with Pseudomonas fluorescens AB254. HortScience 26:1163-1165.

Cantliffe, D.J., E.A. Wolf, and J.M. White. 1975. Improved germination and plant stand of 'Florida Sweet' corn by seed treatment. Proc. Fla. State Hort. Soc. 88:170-173.
Gerber, J.M. and L.A. Caplan. 1989. Priming $s h 2$ sweet corn seed for improved emergence. HortScience 24:854.

Harman, G.E. and A.G. Taylor. 1989. Combining effective strains of Trichoderma harzianum and solid matrix priming to improve biological seed treatments. Plant Dis. 73:631-637.

He, L. and J.S. Burris. 1992. Respiration and carbohydrate metabolism during germination of $s h 2$ and Sh2 sweet corn seed. HortScience 27:13061308.

Headrick, J.M. and J.K. Pataky. 1989. Resistance to kernel infection by Fusarium moniliforme in inbred lines of sweet corn and the effect of infection on emergence. Plant Dis. 73:887-892.

Howell, C.R. 1991. Biological control of pythium damping-off of cotton with seed-coating preparations of Gliocladium virens. Phytopathology 81:738-741.

Howell, C.R., R.D. Stipanovic, and R.D. Lumsden. 1993. Antibiotic production by strains of Gliocladium virens and its relation to biocontrol of cotton seedling diseases. Biocontrol Sci. \& Technol. 3:445-441.

Mohan, S.K. and D.O. Wilson. 1990. Fungi associated with seed and seedling blight of shrunken 2 sweet corn in Idaho. Phytopathology 80:891. (Abstr.)

Murray, G.A. 1990. Priming sweet corn seed to improve emergence under cool conditions. HortScience 25:231.

Parera, C.A. and D.J. Cantliffe. 1990 Improved stand establishment of shrunken 2 sweet corn by seed treatments. Proc. Fla. State Hort. Soc. 103:153-157.

Parera, C.A. and D.J. Cantliffe, 1991. Improved germination and modified imbibition of shrunken 2 sweet corn by seed disinfestation and solid matrix priming. J. Amer. Soc. Hort. Sci. 116:942-945.

Parera, C.A. and D.J. Cantliffe. 1994. Presowing seed treatments to enhance supersweet sweet corn seed and seedling quality. HortScience 29:277-278

Schoen, J.F. and M.M. Kulik. 1977. Towel germination and field emergence of treated and nontreated sweet corn seeds infested with Fusarium moniliforme. J. Seed Technol. 2:48-51.

Styer, R.C. and D.J. Cantliffe. 1983. Relationship between environment during seed development and seed vigor of two endosperm mutants of corn. J. Amer. Soc. Hort. Sci. 108:717-720.

Taylor, A.G., D.E. Klein, and T.H. Whitlow. 1988. SMP: Solid matrix priming of seeds. Sci. Hort. 37:1-11.

Wann, E.V. 1980. Seed vigor and respiration of maize kernels with different endosperm genotypes. J. Amer. Soc. Hort. Sci. 105:31-34. 